\title{
Asymmetric Conjugate Addition of $\alpha, \alpha$-Disubstituted Aldehydes to Nitroalkenes Organocatalyzed by Chiral Monosalicylamides from trans-Cyclohexane-1,2-Diamines
}

\author{
José R. Martínez-Guillén ${ }^{1}$, Jesús Flores-Ferrándiz ${ }^{1}$, Cecilia Gómez ${ }^{1}$, Enrique Gómez-Bengoa ${ }^{2, *}$ \\ and Rafael Chinchilla $1, *$ (D) \\ 1 Department of Organic Chemistry, Faculty of Sciences, and Institute of Organic Synthesis (ISO), \\ University of Alicante, P.O. Box 99, 03080 Alicante, Spain; jramonimg@gmail.com (J.R.M.-G.); \\ jfloresf@gmail.com (J.F.-F.); cgomez@ua.es (C.G.) \\ 2 Department of Organic Chemistry I, University of the Basque Country, P.O. Box 1072, \\ 20080 San Sebastíán, Spain \\ * Correspondence: enrique.gomez@ehu.es (E.G.-B.); chinchilla@ua.es (R.C.); Tel.: +34-965903822 (R.C.)
}

Received: 25 December 2017; Accepted: 9 January 2018; Published: 11 January 2018

\begin{abstract}
Primary amine-salicylamides derived from chiral trans-cyclohexane-1,2-diamines are used as organocatalysts for the enantioselective conjugate addition of $\alpha, \alpha$-disubstituted aldehydes to arylated and heteroarylated nitroalkenes. The reaction is performed in the presence of 4-dimethylaminopyridine as an additive in dichloromethane as a solvent at room temperature. The corresponding enantioenriched $\gamma$-nitroaldehydes are obtained with enantioselectivities up to $95 \%$. Theoretical calculations are used to justify the reasons of the stereoinduction.
\end{abstract}

Keywords: organocatalysis; asymmetric synthesis; Michael addition; nitroalkenes

\section{Introduction}

The asymmetric synthesis of $\gamma$-nitroaldehydes has gained great importance during recent years. They are precursors of $\gamma$-aminobutyric acid analogues (GABAs), which exhibit a range of pharmacological activities including antidepressant, anticonvulsant, anxiolytic and others $[1,2]$. In addition, GABA derivatives can be potent drugs in the treatment of neurodegenerative disorders [3]. Moreover, the presence of the versatile nitro group allows for further transformations to valuable compounds. This is largely due to the utility of the nitro group as a masked functionality to be transformed to a variety of other useful functional groups [4,5], which was well described by Seebach with the term 'synthetic chameleon' [6].

Nowadays, the enantioselective 1,4-addition reaction of enolizable aldehydes to nitroalkenes promoted by a chiral organocatalyst is one of the most common and convenient procedures for achieving the synthesis of $\gamma$-nitroaldehydes in an enantiomerically enriched form [7-12]. Particularly, bifunctional organocatalysts derived from enantiopure trans-cyclohexane-1,2-diamine, a commonly employed chiral auxiliary [13,14], bearing a primary amine and an additional H-bond-forming functionality, have been employed successfully in this transformation (Figure 1). Thus, the use of primary amine-thioureas has been frequent, as exemplified in organocatalyst $\mathbf{1}$ [15], 2 [16] and 3 [17], as well as the Cinchona-derived 4 [18], the isosteviol- and rosin-derived 5 [19] and 6 [20], respectively, and even calix[4]arene-derived compounds [21]. In addition, primary-amine squaramides have been used, as is the case of isosteviol-derived compound 7 [22], and the primary-amine-containing benzimidazole 8 [23] and guanidine 9 [24]. In all these primary-amine organocatalysts, the enantioselectivity is induced by addition 
of a transient enamine to the nitroolefin, which is $\mathrm{H}$-bond-coordinated by the $\mathrm{NO}_{2}$ group to the $\mathrm{NH}^{\prime} \mathrm{s}$ of the catalyst functionality.

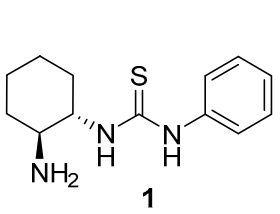<smiles>N[C@@H]1CCCC[C@H]1NC(=S)Nc1cc(C(F)(F)F)cc(C(F)(F)F)c1</smiles><smiles>CC(C)C(NC(=S)N[C@H]1CCCC[C@H]1N)C(=O)NCc1ccccc1</smiles><smiles>C=CC1CC2CCN1C([C@H](NC(=S)NC1CCCCC1N)c1ccnc3ccc(OC)cc13)C2</smiles>

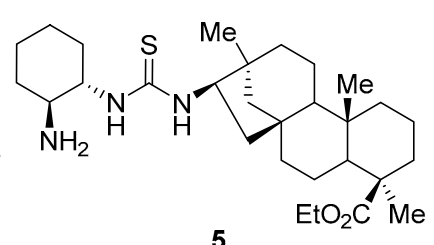<smiles>CC(C)c1ccc2c(c1)CC[C@H]1C(CNC(=S)N[C@H]3CCCC[C@H]3N)[C@@]2(C)CCC[C@@H]1C</smiles>

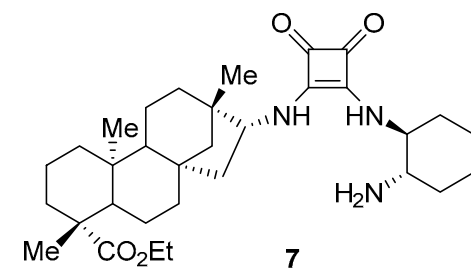<smiles>NC1CCCC[C@H]1Nc1nc2ccccc2[nH]1</smiles><smiles>CC(C)N=C(NC(C)C)NC1CCCCC1N</smiles>

Figure 1. Chiral trans-cyclohexa-1,2-diamine-based organocatalysts employed in the enantioselective conjugate addition of aldehydes to nitroalkenes.

In the last years, our group has been involved in the use of small-size trans-cyclohexane1,2-diamine-derived monocarbamates, such as the mono-Boc-protected diamine $\mathbf{1 0}$ as organocatalysts in the enantioselective conjugate addition reactions of carbonyl compounds to electron-deficient olefins (Figure 2) [25-28]. This paper shows now that a simple monoamidation of a chiral trans-cyclohexane-1,2-diamine with salicylic acid affords a primary amine-bearing salicylamide $\mathbf{1 1}$ (Figure 2), suitable to organocatalyze the asymmetric conjugate addition reaction of the 'difficult' $\alpha, \alpha$-disubstituted aldehydes to nitroalkenes, leading to enantioenriched $\gamma$-nitroaldehydes. Theoretical calculations can explain the observed enantioselectivity of the process.<smiles>CC(C)(C)OC(=O)N[C@H]1CCCC[C@H]1N</smiles>

10<smiles>NC1CCCC[C@H]1NC(=O)c1ccccc1O</smiles>

11

Figure 2. Organocatalysts employed in this study.

\section{Results and Discussion}

The primary amine-salicylamide $\mathbf{1 1}$ employed as organocatalyst in this study was prepared by monoamidation of $(1 S, 2 S)$-cyclohexane-1,2-diamine with phenyl salicylate in refluxing propan-2-ol [29]. The search for the most appropriate reaction conditions (Table 1) was carried out using the model conjugate addition reaction of isobutyraldehyde (12a) to trans- $\beta$-nitrostyrene (13a). Thus, this reaction organocatalyzed by $\mathbf{1 1}(20 \mathrm{~mol} \%)$ in toluene as a solvent at room temperature afforded the corresponding $\gamma$-nitroaldehyde (S)-14aa in $79 \%$ ee but in a very low yield after $2 \mathrm{~d}$ reaction time (Table 1, entry 1). The $(S)$ absolute configuration of the final adduct was determined by comparison of the elution order of the corresponding enantiomers in chiral HPLC with those in the literature [24]. The use of dimethylformamide (DMF) as solvent lowered down dramatically the stereoselectivity of 
the process (Table 1, entry 2), whereas the use of dichloromethane raised the enantioselectivity again up to $84 \%$, but with almost negligible yield (Table 1, entry 3 ).

Table 1. Screening and optimization of the reaction conditions for the model enantioselective conjugate addition.

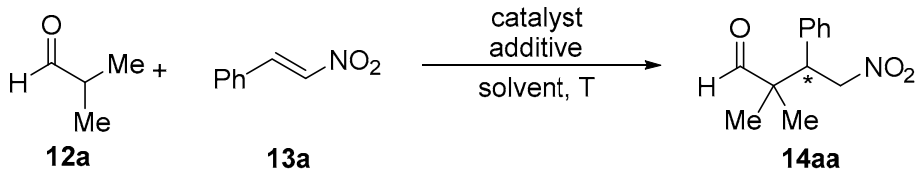

\begin{tabular}{|c|c|c|c|c|c|c|}
\hline Entry & Catalyst (mol \%) & Additive (mol \%) ${ }^{a}$ & Solvent & $t(\mathrm{~d})$ & Yield $(\%)^{b}$ & $e e(\%)^{c}$ \\
\hline 1 & $11(20)$ & - & $\mathrm{PhMe}$ & 2 & $10^{\mathrm{d}}$ & $79(S)$ \\
\hline 2 & $11(20)$ & - & DMF & 2 & 26 & $9(S)$ \\
\hline 3 & $11(20)$ & - & $\mathrm{CH}_{2} \mathrm{Cl}_{2}$ & 2 & $10^{\mathrm{d}}$ & $84(S)$ \\
\hline 4 & $11(20)$ & DMAP (20) & $\mathrm{CH}_{2} \mathrm{Cl}_{2}$ & 2 & 81 & $92(S)$ \\
\hline 5 & $11(20)$ & Imidazole (20) & $\mathrm{CH}_{2} \mathrm{Cl}_{2}$ & 2 & $10^{\mathrm{d}}$ & $76(S)$ \\
\hline 6 & $11(20)$ & Pyridine (20) & $\mathrm{CH}_{2} \mathrm{Cl}_{2}$ & 2 & $10^{\mathrm{d}}$ & $81(S)$ \\
\hline 7 & $11(20)$ & TMG (20) & $\mathrm{CH}_{2} \mathrm{Cl}_{2}$ & 2 & 43 & $91(S)$ \\
\hline 8 & $11(20)$ & DBU (20) & $\mathrm{CH}_{2} \mathrm{Cl}_{2}$ & 2 & 31 & $38(S)$ \\
\hline 9 & $11(20)$ & DABCO (20) & $\mathrm{CH}_{2} \mathrm{Cl}_{2}$ & 2 & 47 & $93(S)$ \\
\hline 10 & $11(20)$ & $\mathrm{PhCO}_{2} \mathrm{H}(20)$ & $\mathrm{CH}_{2} \mathrm{Cl}_{2}$ & 2 & $10^{\mathrm{d}}$ & $71(S)$ \\
\hline 11 & $11(20)$ & $4-\mathrm{O}_{2} \mathrm{NC}_{6} \mathrm{H}_{4} \mathrm{CO}_{2} \mathrm{H}(20)$ & $\mathrm{CH}_{2} \mathrm{Cl}_{2}$ & 2 & $10^{d}$ & $78(S)$ \\
\hline 12 & $11(20)$ & 3,4-(MeO $)_{2} \mathrm{C}_{6} \mathrm{H}_{3} \mathrm{CO}_{2} \mathrm{H}(20)$ & $\mathrm{CH}_{2} \mathrm{Cl}_{2}$ & 2 & $10^{\mathrm{d}}$ & $75(S)$ \\
\hline 13 & $11(10)$ & DMAP (20) & $\mathrm{CH}_{2} \mathrm{Cl}_{2}$ & 2 & 17 & $94(S)$ \\
\hline 14 & $11(20)$ & DMAP (10) & $\mathrm{CH}_{2} \mathrm{Cl}_{2}$ & 2 & 41 & $94(S)$ \\
\hline 15 & $11(20)$ & DMAP (30) & $\mathrm{CH}_{2} \mathrm{Cl}_{2}$ & 2 & 72 & $95(S)$ \\
\hline 16 & ent-11 (20) & DMAP (30) & $\mathrm{CH}_{2} \mathrm{Cl}_{2}$ & 2 & 74 & $95(R)$ \\
\hline 17 & $15(20)$ & DMAP (30) & $\mathrm{CH}_{2} \mathrm{Cl}_{2}$ & 3 & 40 & $79(S)$ \\
\hline 18 & $10(20)$ & DMAP (30) & $\mathrm{CH}_{2} \mathrm{Cl}_{2}$ & 3 & 30 & $65(S)$ \\
\hline
\end{tabular}

a DMAP: 4-Dimethylaminopyridine; TMG: 1,1,3,3-Tetramethylguanidine; DBU: 1,8-Diazabicyclo[5.4.0]undec-7-ene; DABCO: 1,4-Diazabicyclo[2.2.2]octane. ${ }^{\mathrm{b}}$ Isolated yield after flash chromatography. ${ }^{\mathrm{c}}$ Enantioselectivities and absolute stereochemistry determined by chiral HPLC (see Experimental Section). ${ }^{\mathrm{d}}$ Estimated by ${ }^{1} \mathrm{H}-\mathrm{NMR}$ $(400 \mathrm{MHz})$.

The addition of acid or basic additives frequently has proven beneficial in the organocatalyzed conjugate addition of carbonyl compounds to nitroalkenes, not only accelerating the formation of the transient enamine, but supposedly avoiding the formation of stable catalyst-derived byproducts [12]. Therefore, we assayed the model conjugate addition reaction in the presence of 4-dimethylaminopyridine (DMAP, $20 \mathrm{~mol} \%$ ) as a basic additive in dichloromethane as a solvent, now obtaining adduct (S)-14aa in an $81 \%$ isolated yield and with an enantioselectivity of $92 \%$ (Table 1 , entry 4). However, the use of other basic additives resulted in being not so effective. Thus, the presence of imidazole or pyridine as additives gave lower enantioselections and very poor yields (Table 1 , entries 5 and 6), whereas other basic species such as TMG, DBU or DABCO showed less efficiency than DMAP, considering the isolated yield of (S)-14aa (Table 1, entries 7-9). In addition, we also attempted the use of aromatic carboxylic acids as additives, but, in all cases, the achieved enantioselectivities were just moderate and yields were very low (Table 1, entries 10-12).

Considering the couple 11/DMAP as the most efficient catalytic combination, we explore the influence of the ratio between both components. Thus, lowering the organocatalyst loading down to $10 \mathrm{~mol} \%$ and keeping the additive loading to $20 \mathrm{~mol} \%$ gave rise to (S)-14aa in only $17 \%$ yield but in $94 \%$ ee (Table 1, entry 13), whereas keeping the catalyst loading in $20 \mathrm{~mol} \%$ and diminishing the amount of DMAP to $10 \mathrm{~mol} \%$ maintained the ee unaltered, increasing the final yield (Table 1, entry 14). However, loadings of $20 \mathrm{~mol} \%$ of $\mathbf{1 1}$ and $30 \mathrm{~mol} \%$ of DMAP allowed to obtain (S)-14aa in 72\% yield and $95 \%$ ee (Table 1, entry 15).

Expecting to achieve an opposite enantioselection, we also performed the reaction using as organocatalyst ent-11, which was prepared similarly to its enantiomeric counterpart, but using $(1 R, 2 R)$-cyclohexane-1,2-diamine as chirality source (Figure 3$)$. Using this primary amine as 
organocatalyst (20 mol \%) under the most effective reaction conditions (DMAP (30 mol \%), $\mathrm{CH}_{2} \mathrm{Cl}_{2}$, $\mathrm{rt}$ ), adduct $(R)$-14aa was isolated in the same $95 \%$ enantioselectivity than its opposite $(S)$-enantiomer (Table 1 , entry 16).

We were intrigued to determine if the presence of the phenolic $\mathrm{OH}$ on the organocatalyst was a determinant for the high enantioselectivity obtained. Thus, we prepared the primary amine-containing benzamide 15 by reaction of $(1 S, 2 S)$-cyclohexane-1,2-diamine with phenyl benzoate under similar conditions as $\mathbf{1 1}$ (Figure 3). However, under the above optimal reaction conditions, this organocatalyst 15 gave rise to adduct (S)-14aa in only a 79\% ee (Table 1, entry 17). Therefore, the presence of the phenolic $\mathrm{OH}$ in organocatalyst 10 results as being important for achieving a good enantioinduction. It is interesting to note that the use of the monocarbamate $\mathbf{1 0}$ as an organocatalyst was not particularly successful, giving rise to the corresponding adduct in low yield and only $65 \%$ ee (Table 1, entry 18), whereas it has been able to reach up to $96 \%$ ee when employed in a related enantioselective Michael addition of aromatic ketones to nitroalkenes [27].

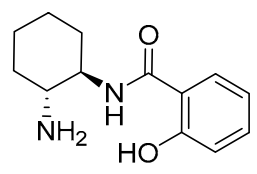

ent-11

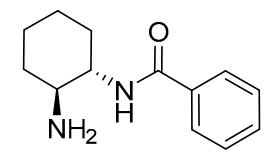

15

Figure 3. Organocatalysts employed in this study.

Next, we extended the addition reaction of isobutyraldehyde to other trans- $\beta$-nitroalkenes $\mathbf{1 3}$ under the most favorable reaction conditions (11 (20 mol \%), DMAP (30 mol \%), $\left.\mathrm{CH}_{2} \mathrm{Cl}_{2}, \mathrm{rt}\right)$, the results being summarized in Table 2. The absolute configuration of the known $\gamma$-nitroaldehydes 14 was assigned in accordance with the elution order of the enantiomers in chiral HPLC when compared to the literature (see Experimental Section).

Thus, when nitroalkenes $\mathbf{1 3 b}$ and $\mathbf{1 3 c}$, bearing electron-releasing groups such as methyl or methoxy in the aromatic ring, were used, the corresponding Michael adducts $(S)$-14ab and $(S)$-14ac were both isolated in enantioselectivities of $92 \%$ (Table 2, entries 2 and 3). In addition, the presence of a dioxolane system on the aromatic ring, as in the nitroolefin $\mathbf{1 3 d}$, lowered the enantioselection down to $85 \%$ (Table 2, entry 4), whereas this was raised up to $94 \%$ when 13 e containing three methoxy groups was used as electrophile (Table 2, entry 5). When halogen groups were present onto the aromatic ring of the nitroalkene, the achieved enantioselectivities were rather uneven. Thus, a fluoro group (13f) gave rise to $(S)$-14af in 92\% ee, whereas chloro groups at 2- (13g) and 4-positions (13h) afforded adducts $(R)$-14ag and (S)-14ah in similar 87 and 88\% ee, respectively (Table 2, entries 6-8), and a bromo group (13i) gave (S)-14ai in 94\% ee (Table 2, entry 9). Moreover, an electron-withdrawing group such as the trifluoromethyl (13j) gave also a good enantioselectivity for (S)-14aj (93\%) (Table 2, entry 10).

When nitroalkene 13k bearing a 2-naphthyl group was employed as Michael acceptor, the corresponding adduct (S)-14ak was obtained in 91\% ee (Table 2, entry 11). In addition, the influence of the presence of heteroarylated rings in the nitroalkene was also explored with the use as Michael acceptors of the 3-pyridinyl- and 2-furanyl-containing nitroalkenes $\mathbf{1 3 1}$ and $\mathbf{1 3 m}$, which gave rise to adducts (S)-14al and (S)-14am in 91 and 92\% ee, respectively (Table 2, entries 12 and 13). 
Table 2. Enantioselective conjugate addition of aldehydes to nitroalkenes organocatalyzed by $\mathbf{1 1 .}$
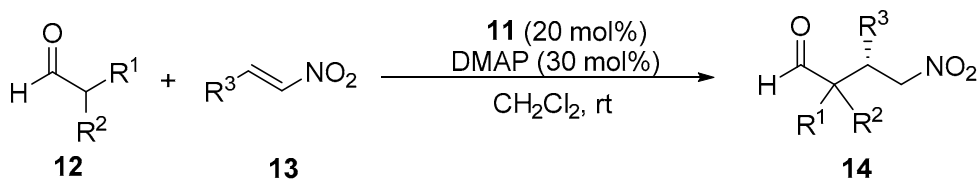

\begin{tabular}{|c|c|c|c|c|c|c|c|c|}
\hline \multirow[t]{2}{*}{ Entry } & \multicolumn{2}{|c|}{ Aldehyde } & \multicolumn{2}{|c|}{$\beta$-Nitroalkene } & \multirow[t]{2}{*}{$t(\mathrm{~d})$} & \multicolumn{3}{|c|}{$\gamma$-Nitroaldehyde } \\
\hline & $\mathrm{R}^{1}, \mathrm{R}^{2}$ & No. & $\mathbf{R}^{3}$ & No. & & No. & Yield (\%) ${ }^{a}$ & $e e^{\mathrm{b}}(\%)^{\mathrm{b}}$ \\
\hline 1 & $\mathrm{Me}, \mathrm{Me}$ & $12 a$ & $\mathrm{Ph}$ & $13 a$ & 2 & $(S)-\mathbf{1 4} \mathbf{a a}$ & 72 & 95 \\
\hline 2 & $\mathrm{Me}, \mathrm{Me}$ & $12 a$ & $4-\mathrm{MeC}_{6} \mathrm{H}_{4}$ & $13 b$ & 2 & $(S)-\mathbf{1 4} \mathbf{a b}$ & 67 & 92 \\
\hline 3 & $\mathrm{Me}, \mathrm{Me}$ & $12 a$ & $4-\mathrm{MeOC}_{6} \mathrm{H}_{4}$ & $13 c$ & 2 & $(S)-14 a c$ & 91 & 92 \\
\hline 4 & $\mathrm{Me}, \mathrm{Me}$ & $12 a$ & $3,4-\left(\mathrm{OCH}_{2} \mathrm{O}\right) \mathrm{C}_{6} \mathrm{H}_{3}$ & $13 d$ & 2 & (S)-14ad & 64 & 85 \\
\hline 5 & $\mathrm{Me}, \mathrm{Me}$ & $12 a$ & $3,4,5-(\mathrm{MeO})_{3} \mathrm{C}_{6} \mathrm{H}_{2}$ & $13 e$ & 2 & $(S)-\mathbf{1 4 a e}$ & 85 & 94 \\
\hline 6 & $\mathrm{Me}, \mathrm{Me}$ & $12 a$ & $4-\mathrm{FC}_{6} \mathrm{H}_{4}$ & $13 f$ & 2 & $(S)-\mathbf{1 4 a f}$ & 62 & 92 \\
\hline 7 & $\mathrm{Me}, \mathrm{Me}$ & $12 a$ & $2-\mathrm{ClC}_{6} \mathrm{H}_{4}$ & $13 g$ & 2 & $(R)-14 a^{c}$ & 50 & 87 \\
\hline 8 & $\mathrm{Me}, \mathrm{Me}$ & $12 a$ & $4-\mathrm{ClC}_{6} \mathrm{H}_{4}$ & $13 \mathrm{~h}$ & 2 & $(S)-14 a h$ & 70 & 88 \\
\hline 9 & $\mathrm{Me}, \mathrm{Me}$ & $12 a$ & $4-\mathrm{BrC}_{6} \mathrm{H}_{4}$ & $13 \mathbf{i}$ & 2 & $(S)-14 \mathbf{a i}$ & 50 & 94 \\
\hline 10 & $\mathrm{Me}, \mathrm{Me}$ & $12 a$ & $4-\mathrm{F}_{3} \mathrm{CC}_{6} \mathrm{H}_{4}$ & $13 \mathbf{j}$ & 2 & $(S)-\mathbf{1 4} \mathbf{a j}$ & 51 & 93 \\
\hline 11 & $\mathrm{Me}, \mathrm{Me}$ & $12 a$ & 2-Naphthyl & $13 k$ & 2 & (S)-14ak & 68 & 91 \\
\hline 12 & $\mathrm{Me}, \mathrm{Me}$ & $12 a$ & 3-Pyridinyl & 131 & 2 & $(S)-14 a \mathbf{a l}$ & 43 & 91 \\
\hline 13 & $\mathrm{Me}, \mathrm{Me}$ & $12 a$ & 2-Furanyl & $13 \mathrm{~m}$ & 2 & (S)-14am & 82 & 92 \\
\hline 14 & $-\left(\mathrm{CH}_{2}\right)_{4}-$ & $12 b$ & $\mathrm{Ph}$ & $13 a$ & 3 & $(S)-\mathbf{1 4 b a}$ & 60 & 94 \\
\hline
\end{tabular}

${ }^{a}$ Isolated yield after flash chromatography. ${ }^{\mathrm{b}}$ Enantioselectivities determined by chiral HPLC. Absolute configuration assigned by the order of elution of the enantiomers in chiral HPLC (See Experimental Section).

${ }^{c}$ Apparent change in the sense of the enantioselectivity because of the application of the Cahn-Ingold-Prelog rules.

We also explored the conjugate addition reaction of other $\alpha, \alpha$-disubstituted aldehydes with nitroalkene 13a. Thus, when cyclopentanecarbaldehyde (12b) was used, the corresponding Michael adduct (S)-14ba was isolated in an excellent 94\% ee (Table 2, entry 14). However, when diphenylacetaldehyde or 2-phenylpropionaldehyde were used as pro-nucleophiles, almost negligible amounts $(5 \%)$ of the corresponding adducts were detected as racemates.

To get further insight into the origin of the enantioselectivity, we carried out theoretical calculations on the reaction between isobutyraldehyde 12a and nitroalkene 13a in the presence of catalyst 11 . A salient feature of this catalyst is the presence of a phenolic $\mathrm{OH}$ in the ortho position, which seems to play a key role to enhance the activity and/or selectivity of the process. To understand this intriguing behavior, the results obtained with $\mathbf{1 1}$ were compared with those of the less active catalyst 15, and also with the model system 16 (Figure 4), which bears the $\mathrm{OH}$ group para to the carbonyl substituent. This species was not checked experimentally but would give us a better understanding of the relevance of the ortho substitution for the reactivity.<smiles>NC1CCCCC1NC(=O)c1ccccc1O</smiles>

11

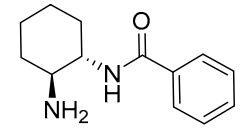

15<smiles>NC1CCCCC1NC(=O)c1ccc(O)cc1</smiles>

16

Figure 4. Model catalysts employed in the computational study.

As expected, the initial formation of an enamine between the catalyst free amine and the aldehyde is followed by attack to the nitrostyrene according to Seebach's synclinal model (endo attack) [30,31], which was confirmed by the much higher energy of other possible approaches, like exo depicted in Figure 5. The synclinal model secures a diastereoselective approach of the reacting faces of enamine and alkene, meaning that the lower face (in our view) of the enamine reacts with the Re face of alkene and the opposite, the upper face of enamine with the Si face of alkene. As a direct consequence, the approach of the alkene from each side of the enamine produces a single diastereoisomer. 


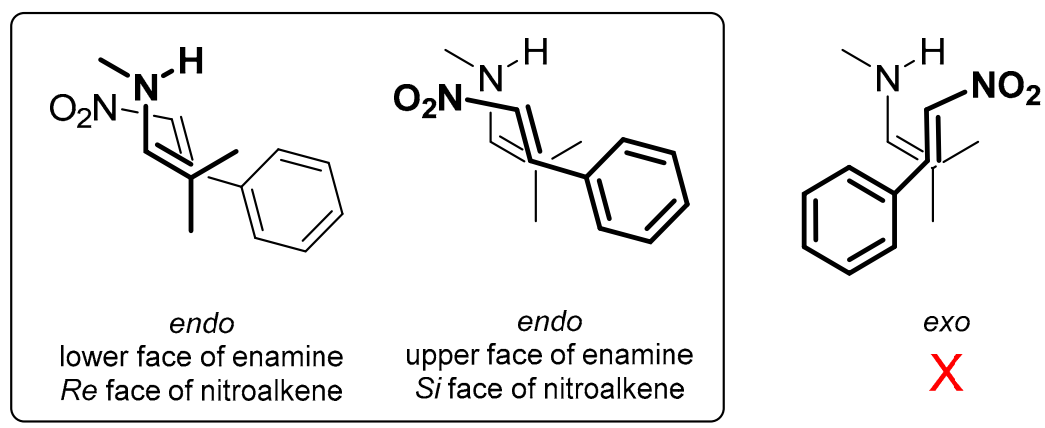

Figure 5. Seebach's synclinal model for the approach of enamine and nitroalkene faces.

The different conformations of the both cyclohexyl-amine substituents in the catalysts were taken into consideration. The amine side arms of cyclohexane possess several free rotating bonds, and, among all the possibilities checked, we selected the most stable ones, outlined in Figure 6. In them, the enamine and amide groups occupy the equatorial positions of the cyclohexane, pointing up and down, respectively. The fragment NH-C-C-NH is in staggered conformation. We then located the transition states for 11, corresponding to the different approaches, taking into account all possible $\mathrm{H}$-bonding activation networks of the $\mathrm{NH}$ and $\mathrm{OH}$ groups (Figure 6). As expected, the amide $\mathrm{NH}$ group in $\mathbf{1 1}$ is H-binding the nitro group of the electrophile, activating it for the nucleophilic attack, and inducing a good differentiation of both faces of the enamine. The lower face approach in TS1 is much lower in energy $(9.8 \mathrm{kcal} / \mathrm{mol})$ than TS2 $(15.8 \mathrm{kcal} / \mathrm{mol})$, justifying the experimental selectivity. The origin of the selectivity is clearly linked to the high strain developing in TS2 to accommodate the $\mathrm{H}$-bond between the nitro and amide groups. We could demonstrate that $\mathrm{OH}$ is not actively participating in the activation of the nitro group, since the barrier in TS3 is clearly higher $(18.4 \mathrm{kcal} / \mathrm{mol})$ than in TS1, even if the amide-NH in TS3 is slightly contributing to increase the acidity of the $\mathrm{OH}$ through Brønsted assistance $\left(\delta_{\mathrm{O}-\mathrm{H}}=1.98 \AA\right)$. Interestingly, this H-bonding network alternative is more flexible, and the energy difference between TS3 and TS4 is fairly reduced to only $2.0 \mathrm{kcal} / \mathrm{mol}$.

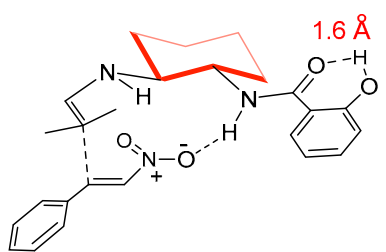

TS1, $\Delta \mathrm{G}^{\ddagger}=9.8 \mathrm{kcal} / \mathrm{mol}$

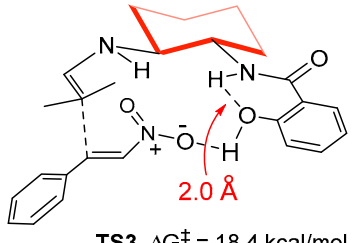

TS3, $\Delta \mathrm{G}^{\ddagger}=18.4 \mathrm{kcal} / \mathrm{mol}$

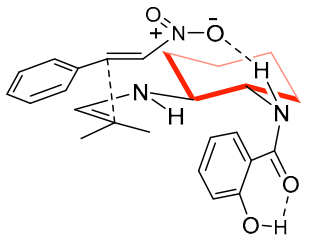

TS2, $\Delta G^{\ddagger}=15.8 \mathrm{kcal} / \mathrm{mol}$

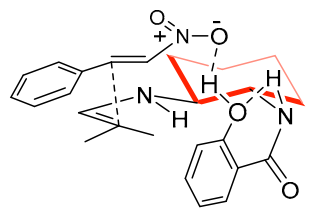

TS4, $\Delta \mathrm{G}^{\ddagger}=20.4 \mathrm{kcal} / \mathrm{mol}$

Figure 6. Computed Free energies and structures of the diastereoselective transition states for the C-C bond formation in the presence of catalyst $\mathbf{1 1 .}$

Initially, the tentative role of $\mathrm{OH}$ in promoting the reaction was assigned to its suitability to enhance the H-bond donor ability of the amide group through an extra activation by Brønsted acid-assistance $\left(\delta_{\mathrm{O}-\mathrm{H}}=1.62 \AA\right.$ in TS1). However, to our surprise, the calculations predicted a similar reactivity and selectivity for species $\mathbf{1 5}$ and $\mathbf{1 6}$ (Figure 4), where the $\mathrm{OH}$ group is lacking or cannot interact with the amide because it is positioned at the para position. In fact, the activation energies 
of transition states TS5 and TS7 are undistinguishable from TS1 (Figure 7), and a similar situation is found comparing TS2, TS6 and TS8. Thus, the presence or absence of the ortho OH group in $\mathbf{1 1}$ is not predicted computationally to have a significant effect on both reactivity and selectivity.

In this regard, there is an increasing number of studies indicating that $\mathrm{C}-\mathrm{C}$ bond formation between enamine and nitroalkene is facile and might not be the rate-determining step in catalyzed processes [32-34]. Instead, the highest energy along the reaction coordinate would correspond to the protonation of the highly stable cyclic intermediates that arise after the $\mathrm{C}-\mathrm{C}$ bond formation. Thus, the rate- and stereodetermining steps might not be identical. We checked this alternative in our case, and could locate two cyclic intermediates, 17 and 18 (Figure 8), showing energies of -8.6 and $-6.1 \mathrm{kcal} / \mathrm{mol}$ with respect to the starting materials. Furthermore, the lowest transition state for their protonation (TS9) would be the rate limiting step of our cycle, presenting a Free energy barrier of $28.0 \mathrm{kcal} / \mathrm{mol}$ (from 17).
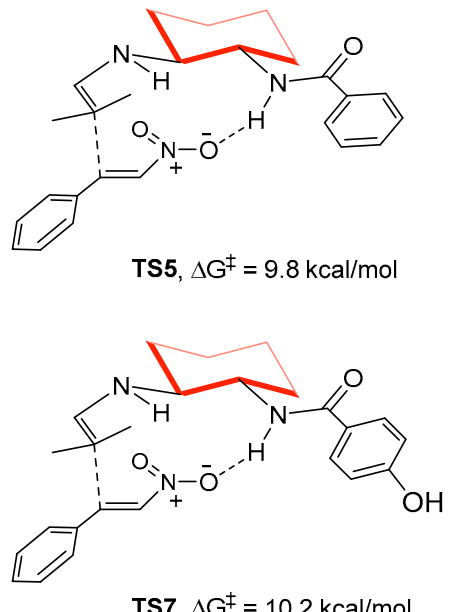

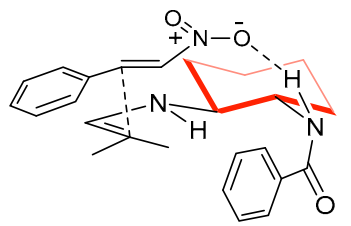

TS6, $\Delta \mathrm{G}^{\ddagger}=16.0 \mathrm{kcal} / \mathrm{mol}$

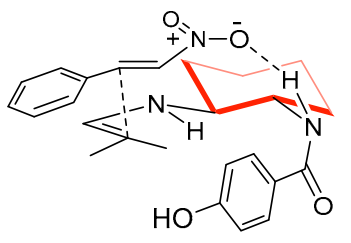

TS8, $\Delta \mathrm{G}^{\ddagger}=16.8 \mathrm{kcal} / \mathrm{mol}$

Figure 7. Computed Free energies and structures of the diastereoselective transition states for the C-C bond formation in the presence of the catalysts $\mathbf{1 5}$ and $\mathbf{1 6 .}$

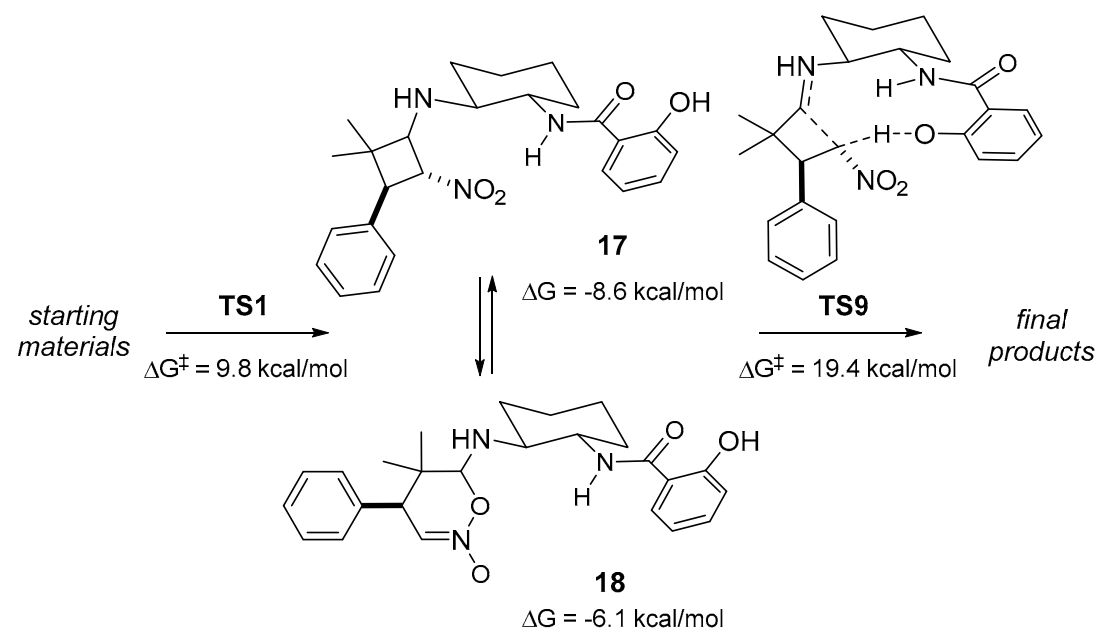

Figure 8. Computed Free energies and structures for the formation of the cyclic intermediates and their protonation to the final products.

A similar protonation cannot obviously be envisioned for catalytic species lacking ortho-phenol, like 15 and 16, and, in those cases, adventitious water must be responsible for the cleavage and 
protonation of the proposed intermediates, although at a higher energetic cost. As a confirmation, we were able to locate some transition states involving a molecule of water, which are in every case at least 1.5-2.0 kcal/mol higher in energy than TS9. Thus, we can confirm that also in our case the stereoselectivity is controlled during the C-C bond formation event, but the reaction rate is governed by the protonation and cleavage of the stable cyclic intermediates. It is at this point where the phenol moiety plays a crucial role, nicely explaining the experimental results.

\section{Experimental Section}

\subsection{General Information}

All the reagents and solvents employed were of the best grade available and were used without further purification. The ${ }^{1} \mathrm{H}$ - and ${ }^{13} \mathrm{C}-\mathrm{NMR}$ spectra were recorded at room temperature on a Bruker (Bruker, Billerica, MA, USA) AC-400 at $400 \mathrm{MHz}$ and $101 \mathrm{MHz}$, respectively, using TMS as internal standard. IR spectra were measured on a Nicolet Impact 400D-FT instrument (Thermo Fisher Scientific, Waltham, MA, USA). Electron Ionized Mass Spectrometry (EIMS) spectra were obtained on an Agilent Technologies GC/MS-5973N equipment (Agilent Technologies, Santa Clara, CA, USA) at 70 eV. HR-MS spectra were obtained on an Agilent Technologies 7200 Accurate-Mass Q-TOF GC/MS equipment at using EI at $70 \mathrm{eV}$. Compounds $\mathbf{1 1}$ and ent-11 were obtained as described [29]. Nitroalkenes 13 were purchased or prepared following a reported procedure [35], except 131, which was obtained differently [36]. Absolute configuration for adducts 14 was determined according to the order of elution of their enantiomers in chiral HPLC. The absolute configuration of the not described compounds 14ad and 14ae was assigned by analogy. Reference racemic samples of adducts 14 were obtained by performing the conjugate addition reaction using 4-methylbenzylamine $(20 \mathrm{~mol} \%)$ as organocatalyst in toluene as a solvent at room temperature.

\subsection{General Procedure for the Asymmetric Conjugate Addition Reaction}

To a solution of 10, 11, ent-11 or $15(0.04 \mathrm{mmol})$, the nitroalkene $\mathbf{1 3}(0.2 \mathrm{mmol})$ and DMAP $(7.3 \mathrm{mg}$, $0.06 \mathrm{mmol})$ in $\mathrm{CH}_{2} \mathrm{Cl}_{2}(0.3 \mathrm{~mL})$ was added the aldehyde $12(0.4 \mathrm{mmol})$ and the mixture was stirred at $\mathrm{rt}$ until completion (TLC). The reaction was quenched with $\mathrm{HCl} 2 \mathrm{~N}(10 \mathrm{~mL})$ and the mixture was extracted with AcOEt $(3 \times 10 \mathrm{~mL})$. The organic phase was washed with sat. $\mathrm{NaHCO}_{3}(2 \times 10 \mathrm{~mL})$, dried over $\mathrm{MgSO}_{4}$, and the solvent was evaporated (15 Torr) to get the crude product, which was purified by silica gel chromatography ( $n$-hexane/AcOEt gradients). Known adducts 14 were identified by comparison of their NMR data with those of the literature (Supplementary Materials NMR spectra). Their enantiomeric excesses were determined by chiral HPLC using the conditions described in each case (Supplementary Materials HPLC chromatograms). Not described compounds 14ad and 14ae have been fully characterized.

2,2-Dimethyl-4-nitro-3-phenylbutanal (14aa) [24]. Colorless oil; ${ }^{1} \mathrm{H}-\mathrm{NMR}\left(\mathrm{CDCl}_{3}\right): \delta_{H}=9.52(\mathrm{~s}, 1 \mathrm{H})$, 7.35-7.28 (m, 3H), 7.22-7.17 (m, 2H), $4.85(\mathrm{dd}, J=13.1,11.3 \mathrm{~Hz}, 1 \mathrm{H}), 4.69(\mathrm{dd}, J=13.1,4.2 \mathrm{~Hz}, 1 \mathrm{H})$, $3.79(\mathrm{dd}, J=11.3,4.2 \mathrm{~Hz}, 1 \mathrm{H}), 1.12(\mathrm{~s}, 3 \mathrm{H}), 0.99(\mathrm{~s}, 3 \mathrm{H}) \mathrm{ppm} ;{ }^{13} \mathrm{C}-\mathrm{NMR}\left(\mathrm{CDCl}_{3}\right): \delta_{C}=204.2,135.3,129.0$, 128.6, 128.0, 76.2, 48.3 48.1, 21.5, 18.7 ppm; HPLC: Chiralpak OD-H, $\lambda=210$ nm, n-hexane/2-propanol, $80: 20,1.0 \mathrm{~mL} / \mathrm{min}, \mathrm{t}_{\mathrm{r}}(R)=13.4 \mathrm{~min}, \mathrm{t}_{\mathrm{r}}(S)=19.2 \mathrm{~min}$.

2,2-Dimethyl-4-nitro-3-(p-tolyl)butanal (14ab) [24]. Colorless oil; ${ }^{1} \mathrm{H}-\mathrm{NMR}\left(\mathrm{CDCl}_{3}\right): \delta_{H}=9.52(\mathrm{~s}, 1 \mathrm{H})$, $7.13(\mathrm{~d}, J=8.0 \mathrm{~Hz}, 2 \mathrm{H}), 7.08(\mathrm{~d}, J=8.2 \mathrm{~Hz}, 2 \mathrm{H}), 4.83(\mathrm{dd}, J=12.9,11.4 \mathrm{~Hz}, 1 \mathrm{H}), 4.67(\mathrm{dd}, J=12.9,4.2 \mathrm{~Hz}$, $1 \mathrm{H}), 3.74(\mathrm{dd}, J=11.4,4.2 \mathrm{~Hz}, 1 \mathrm{H}), 2.32(\mathrm{~s}, 3 \mathrm{H}), 1.12(\mathrm{~s}, 3 \mathrm{H}), 1.00(\mathrm{~s}, 3 \mathrm{H}) \mathrm{ppm} ;{ }^{13} \mathrm{C}-\mathrm{NMR}\left(\mathrm{CDCl}_{3}\right)$ : $\delta_{C}=204.4,137.8,132.1,129.3,128.9,76.3,48.2,48.1,21.5,21.0,18.8$ ppm; HPLC: Chiralpak OD-H, $\lambda=210 \mathrm{~nm}$, $n$-hexane/2-propanol, 80:20, $1.0 \mathrm{~mL} / \mathrm{min}, \mathrm{t}_{\mathrm{r}}(R)=9.7 \mathrm{~min}, \mathrm{t}_{\mathrm{r}}(S)=13.2 \mathrm{~min}$.

3-(4-Methoxyphenyl)-2,2-dimethyl-4-nitrobutanal (14ac) [24]. Colorless oil; ${ }^{1} \mathrm{H}-\mathrm{NMR}\left(\mathrm{CDCl}_{3}\right): \delta_{H}=9.51$ $(\mathrm{s}, 1 \mathrm{H}), 7.12(\mathrm{~d}, J=8.7 \mathrm{~Hz}, 2 \mathrm{H}), 6.85(\mathrm{~d}, J=8.8 \mathrm{~Hz}, 2 \mathrm{H}), 4.81(\mathrm{dd}, J=12.8,11.4 \mathrm{~Hz}, 1 \mathrm{H}), 4.66(\mathrm{dd}, J=12.8$, $4.2 \mathrm{~Hz}, 1 \mathrm{H}), 3.78(\mathrm{~s}, 3 \mathrm{H}), 3.73(\mathrm{dd}, J=11.4,4.2 \mathrm{~Hz}, 1 \mathrm{H}), 1.11(\mathrm{~s}, 3 \mathrm{H}), 0.99(\mathrm{~s}, 3 \mathrm{H}) \mathrm{ppm} ;{ }^{13} \mathrm{C}-\mathrm{NMR}\left(\mathrm{CDCl}_{3}\right)$ : 
$\delta_{C}=204.4,159.2,130.0,127.0,114.0,76.4,55.1,48.3,47.7,21.4,18.7$ ppm; HPLC: Chiralpak OD-H, $\lambda=210 \mathrm{~nm}, n$-hexane/2-propanol, 80:20, $1.0 \mathrm{~mL} / \mathrm{min}, \mathrm{t}_{\mathrm{r}}(R)=12.0 \mathrm{~min}, \mathrm{t}_{\mathrm{r}}(S)=16.1 \mathrm{~min}$.

3-(Benzo[d][1,3]dioxol-5-yl)-2,2-dimethyl-4-nitrobutanal (14ad). Colorless oil; IR (ATR): $v=2972,2904$, 2817, 1722, 1552, 1491, 1444, 1376, 1241, 1038, 931, $816 \mathrm{~cm}^{-1},{ }^{1} \mathrm{H}-\mathrm{NMR}\left(\mathrm{CDCl}_{3}\right): \delta_{H}=9.51(\mathrm{~s}, 1 \mathrm{H})$, $6.75(\mathrm{~d}, J=8.0 \mathrm{~Hz}, 1 \mathrm{H}), 6.69(\mathrm{~d}, J=1.8 \mathrm{~Hz}, 1 \mathrm{H}), 6.65(\mathrm{dd}, J=8.0,1.8 \mathrm{~Hz}, 1 \mathrm{H}), 5.96(\mathrm{~s}, 2 \mathrm{H})$, $4.78(\mathrm{dd}, J=13.0,11.4 \mathrm{~Hz}, 1 \mathrm{H}), 4.65(\mathrm{dd}, J=13.0,4.2 \mathrm{~Hz}, 1 \mathrm{H}), 3.70(\mathrm{dd}, J=11.4,4.2 \mathrm{~Hz}, 1 \mathrm{H}), 1.13(\mathrm{~s}, 3 \mathrm{H})$, $1.02(\mathrm{~s}, 3 \mathrm{H}) \mathrm{ppm} ;{ }^{13} \mathrm{C}-\mathrm{NMR}\left(\mathrm{CDCl}_{3}\right): \delta_{\mathrm{C}}=204.2,147.9,147.4,128.8,122.6,109.1,108.3,101.2,76.5,48.3$, 21.6, 19.0 ppm; MS (EI, $70 \mathrm{eV}): m / z(\%)=265\left(\mathrm{M}^{+}, 10\right), 148(100) ; \mathrm{HR}-\mathrm{MS}(\mathrm{EI}): \mathrm{m} / z$ calcd. for $\mathrm{C}_{13} \mathrm{H}_{15} \mathrm{NO}_{5}$ $[\mathrm{M}]^{+}:$265.0952, found: 265.0947; HPLC: Chiralpak OD-H, $\lambda=210 \mathrm{~nm}, n$-hexane/2-propanol, 80:20, $1.0 \mathrm{~mL} / \mathrm{min}, \mathrm{t}_{\mathrm{r}}(R)=17.2 \mathrm{~min}, \mathrm{t}_{\mathrm{r}}(S)=23.0 \mathrm{~min}$.

2,2-Dimethyl-4-nitro-3-(3,4,5-trimethoxyphenyl)butanal (14ae). Colorless oil; IR (ATR): $v=2972,2939$, $2835,1722,1589,1552,1460,1242,1124,1005,729 \mathrm{~cm}^{-1} ;{ }^{1} \mathrm{H}-\mathrm{NMR}\left(\mathrm{CDCl}_{3}\right): \delta_{H}=9.52(\mathrm{~s}, 1 \mathrm{H}), 6.38(\mathrm{~s}, 2 \mathrm{H})$, $4.85(\mathrm{dd}, J=13.1,11.3 \mathrm{~Hz}, 1 \mathrm{H}), 4.69(\mathrm{dd}, J=13.1,4.2 \mathrm{~Hz}, 1 \mathrm{H}), 3.85(\mathrm{~s}, 6 \mathrm{H}), 3.83(\mathrm{~s}, 3 \mathrm{H}), 3.70(\mathrm{dd}, J=11.3$, $4.2 \mathrm{~Hz}, 1 \mathrm{H}), 1.16(\mathrm{~s}, 3 \mathrm{H}), 1.06(\mathrm{~s}, 3 \mathrm{H}) \mathrm{ppm} ;{ }^{13} \mathrm{C}-\mathrm{NMR}\left(\mathrm{CDCl}_{3}\right): \delta_{\mathrm{C}}=204.3,153.1,137.7,131.0,106.2,76.3$, 60.7, 56.1, 48.9, 48.2, 21.7, 19.3 ppm; MS (EI, $70 \mathrm{eV}): m / z(\%)=311\left(\mathrm{M}^{+}, 16\right), 194$ (100), 179 (35); HR-MS (EI): $m / z$ calcd. for $\mathrm{C}_{15} \mathrm{H}_{21} \mathrm{NO}_{6}$ [M] ${ }^{+}: 311.1369$, found: 311.1367; HPLC: Chiralpak OD-H, $\lambda=210 \mathrm{~nm}$, $n$-hexane/2-propanol, 80:20, $1.0 \mathrm{~mL} / \mathrm{min}, \mathrm{t}_{\mathrm{r}}(R)=18.2 \mathrm{~min}, \mathrm{t}_{\mathrm{r}}(S)=20.7 \mathrm{~min}$.

3-(4-Fluorophenyl)-2,2-dimethyl-4-nitrobutanal (14af) [24]. Colorless oil; ${ }^{1} \mathrm{H}-\mathrm{NMR}\left(\mathrm{CDCl}_{3}\right): \delta_{H}=9.51(\mathrm{~s}, 1 \mathrm{H})$, 7.21-7.17 (m, 2H), 7.05-7.01 (m, 2H), $4.82(\mathrm{dd}, J=13.1,11.4 \mathrm{~Hz}, 1 \mathrm{H}), 4.69(\mathrm{dd}, J=13.1,4.2 \mathrm{~Hz}$, $1 \mathrm{H}), 3.78(\mathrm{dd}, J=11.4,4.2 \mathrm{~Hz}, 1 \mathrm{H}), 1.12(\mathrm{~s}, 3 \mathrm{H}), 1.01(\mathrm{~s}, 3 \mathrm{H}) \mathrm{ppm} ;{ }^{13} \mathrm{C}-\mathrm{NMR}\left(\mathrm{CDCl}_{3}\right): \delta_{\mathrm{C}}=204.0$, $162.4(\mathrm{~d}, J=247.4 \mathrm{~Hz}), 131.2(\mathrm{~d}, J=3.1 \mathrm{~Hz}), 130.6(\mathrm{~d}, J=8.2 \mathrm{~Hz}), 115.7(\mathrm{~d}, J=21.5 \mathrm{~Hz}), 76.3,48.2,47.7,21.6$, $18.8 \mathrm{ppm}$; HPLC: Chiralpak OD-H, $\lambda=210 \mathrm{~nm}, n$-hexane $/ 2$-propanol, $80: 20,1.0 \mathrm{~mL} / \mathrm{min}, \mathrm{t}_{\mathrm{r}}(R)=11.1 \mathrm{~min}$, $\mathrm{t}_{\mathrm{r}}(S)=17.8 \mathrm{~min}$.

3-(2-Chlorophenyl)-2,2-dimethyl-4-nitrobutanal (14ag) [37]. Colorless oil; ${ }^{1} \mathrm{H}-\mathrm{NMR}\left(\mathrm{CDCl}_{3}\right): \delta_{H}=9.55(\mathrm{~s}, 1 \mathrm{H})$, 7.44-7.40 (m, 1H), 7.31-7.21 (m, 3H), 4.89-4.80 (m, 1H), $4.73(\mathrm{dd}, J=13.3,4.1 \mathrm{~Hz}, 1 \mathrm{H}), 4.63(\mathrm{dd}, J=11.3$, $3.5 \mathrm{~Hz}, 1 \mathrm{H}), 1.17(\mathrm{~s}, 3 \mathrm{H}), 1.08(\mathrm{~s}, 3 \mathrm{H}) \mathrm{ppm} ;{ }^{13} \mathrm{C}-\mathrm{NMR}\left(\mathrm{CDCl}_{3}\right): \delta_{\mathrm{C}}=203.8,135.8,133.7,130.4,129.1,128.2$, 127.1 , 76.2, 49.0, 42.4, 20.9, 18.6 ppm; HPLC: Chiralpak OD-H, $\lambda=210 \mathrm{~nm}, n$-hexane/2-propanol, 80:20, $1.0 \mathrm{~mL} / \mathrm{min}, \mathrm{t}_{\mathrm{r}}(S)=11.1 \mathrm{~min}, \mathrm{t}_{\mathrm{r}}(R)=27.9 \mathrm{~min}$.

3-(4-Chlorophenyl)-2,2-dimethyl-4-nitrobutanal (14ah) [24]. Colorless oil; ${ }^{1} \mathrm{H}-\mathrm{NMR}\left(\mathrm{CDCl}_{3}\right): \delta_{H}=9.50$ $(\mathrm{s}, 1 \mathrm{H}), 7.32(\mathrm{~d}, J=8.5 \mathrm{~Hz}, 2 \mathrm{H}), 7.15(\mathrm{~d}, J=8.5 \mathrm{~Hz}, 2 \mathrm{H}), 4.83(\mathrm{dd}, J=13.1,11.4 \mathrm{~Hz}, 1 \mathrm{H}), 4.69(\mathrm{dd}, J=13.1$, $4.2 \mathrm{~Hz}, 1 \mathrm{H}), 3.77(\mathrm{dd}, J=11.4,4.2 \mathrm{~Hz}, 1 \mathrm{H}), 1.12(\mathrm{~s}, 3 \mathrm{H}), 1.01(\mathrm{~s}, 3 \mathrm{H}) \mathrm{ppm} ;{ }^{13} \mathrm{C}-\mathrm{NMR}\left(\mathrm{CDCl}_{3}\right)$ : $\delta_{C}=203.8,134.1,133.9,130.4,128.9,76.1,48.1,47.8,21.7,18.8$ ppm; HPLC: Chiralpak OD-H, $\lambda=210 \mathrm{~nm}$, $n$-hexane $/ 2$-propanol, 80:20, $1.0 \mathrm{~mL} / \mathrm{min}, \mathrm{t}_{\mathrm{r}}(R)=11.9 \mathrm{~min}, \mathrm{t}_{\mathrm{r}}(S)=17.6 \mathrm{~min}$.

3-(4-Bromophenyl)-2,2-dimethyl-4-nitrobutanal (14ai) [24]. Colorless oil; ${ }^{1} \mathrm{H}-\mathrm{NMR}\left(\mathrm{CDCl}_{3}\right): \delta_{H}=9.50$ $(\mathrm{s}, 1 \mathrm{H}), 7.47(\mathrm{~d}, J=8.5 \mathrm{~Hz}, 2 \mathrm{H}), 7.09(\mathrm{~d}, J=8.5 \mathrm{~Hz}, 2 \mathrm{H}), 4.82(\mathrm{dd}, J=13.2,11.4 \mathrm{~Hz}, 1 \mathrm{H}), 4.69(\mathrm{dd}, J=13.2$, $4.1 \mathrm{~Hz}, 1 \mathrm{H}), 3.76(\mathrm{dd}, J=11.4,4.1 \mathrm{~Hz}, 1 \mathrm{H}), 1.12(\mathrm{~s}, 3 \mathrm{H}), 1.01(\mathrm{~s}, 3 \mathrm{H}) \mathrm{ppm} ;{ }^{13} \mathrm{C}-\mathrm{NMR}\left(\mathrm{CDCl}_{3}\right)$ : $\delta_{C}=203.8,134.5,131.9,130.7,122.2,76.0,48.1,47.9,21.7,18.9$ ppm; HPLC: Chiralpak OD-H, $\lambda=210 \mathrm{~nm}$, $n$-hexane/2-propanol, 80:20, $1.0 \mathrm{~mL} / \mathrm{min}, \mathrm{t}_{\mathrm{r}}(R)=14.0 \mathrm{~min}, \mathrm{t}_{\mathrm{r}}(S)=19.6 \mathrm{~min}$.

2,2-Dimethyl-4-nitro-3-(4-(trifluoromethyl)phenyl)butanal (14aj) [38]. Colorless oil; ${ }^{1} \mathrm{H}-\mathrm{NMR}\left(\mathrm{CDCl}_{3}\right)$ : $\delta_{H}=9.50(\mathrm{~s}, 1 \mathrm{H}), 7.61(\mathrm{~d}, J=8.2 \mathrm{~Hz}, 3 \mathrm{H}), 7.36(\mathrm{~d}, J=8.2 \mathrm{~Hz}, 2 \mathrm{H}), 4.89(\mathrm{dd}, J=13.3,11.4 \mathrm{~Hz}, 1 \mathrm{H})$, $4.74(\mathrm{dd}, J=13.3,4.1 \mathrm{~Hz}, 1 \mathrm{H}), 3.88(\mathrm{dd}, J=11.4,4.1 \mathrm{~Hz}, 1 \mathrm{H}), 1.14(\mathrm{~s}, 3 \mathrm{H}), 1.02(\mathrm{~s}, 3 \mathrm{H}) \mathrm{ppm} ;{ }^{13} \mathrm{C}-\mathrm{NMR}$ $\left(\mathrm{CDCl}_{3}\right): \delta_{C}=203.5,139.8,130.4(\mathrm{q}, J=32.7 \mathrm{~Hz}), 125.7(\mathrm{q}, J=3.6 \mathrm{~Hz}), 123.8(\mathrm{q}, J=272.2 \mathrm{~Hz}), 75.9$, 48.1, 21.8, 18.9 ppm; HPLC: Chiralpak OD-H, $\lambda=210 \mathrm{~nm}, n$-hexane/2-propanol, 80:20, $1.0 \mathrm{~mL} / \mathrm{min}$, $\mathrm{t}_{\mathrm{r}}(R)=11.7 \mathrm{~min}, \mathrm{t}_{\mathrm{r}}(S)=18.5 \mathrm{~min}$.

2,2-Dimethyl-3-(naphthalen-2-yl)-4-nitrobutanal (14ak) [24]. Colorless oil; ${ }^{1} \mathrm{H}-\mathrm{NMR}\left(\mathrm{CDCl}_{3}\right): \delta_{H}=9.57$ $(\mathrm{s}, 1 \mathrm{H}), 7.84-7.82(\mathrm{~m}, 3 \mathrm{H}), 7.68(\mathrm{~d}, J=1.3 \mathrm{~Hz}, 1 \mathrm{H}), 7.54-7.46(\mathrm{~m}, 2 \mathrm{H}), 7.34(\mathrm{dd}, J=8.5,1.9 \mathrm{~Hz}, 1 \mathrm{H})$, $5.00(\mathrm{dd}, J=13.1,11.3 \mathrm{~Hz}, 1 \mathrm{H}), 4.79(\mathrm{dd}, J=13.1,4.1 \mathrm{~Hz}, 1 \mathrm{H}), 3.97(\mathrm{dd}, J=11.3,4.1 \mathrm{~Hz}, 1 \mathrm{H}), 1.19(\mathrm{~s}, 3 \mathrm{H})$, 
$1.05(\mathrm{~s}, 3 \mathrm{H}) \mathrm{ppm} ;{ }^{13} \mathrm{C}-\mathrm{NMR}\left(\mathrm{CDCl}_{3}\right): \delta_{\mathrm{C}}=204.2,133.0,132.9,132.8,128.4,128.3,127.8,127.6,126.5$, 126.5, 126.3 , 76.3, 48.6, 48.4, 21.7, 19.0 ppm; HPLC: Chiralpak OD-H, $\lambda=210 \mathrm{~nm}$, n-hexane/2-propanol, $70: 30,1.0 \mathrm{~mL} / \mathrm{min}, \mathrm{t}_{\mathrm{r}}(R)=16.4 \mathrm{~min}, \mathrm{t}_{\mathrm{r}}(S)=29.6 \mathrm{~min}$.

2,2-Dimethyl-4-nitro-3-(pyridin-3-yl)butanal (14al) [24]. Colorless oil; ${ }^{1} \mathrm{H}-\mathrm{NMR}\left(\mathrm{CDCl}_{3}\right): \delta_{H}=9.50(\mathrm{~s}, 1 \mathrm{H})$, $8.56(\mathrm{~d}, J=3.9 \mathrm{~Hz}, 1 \mathrm{H}), 8.51(\mathrm{~s}, 1 \mathrm{H}), 7.63-7.57(\mathrm{~m}, 1 \mathrm{H}), 7.30(\mathrm{dd}, J=8.3,5.2 \mathrm{~Hz}, 1 \mathrm{H}), 4.89$ (dd, $J=13.3$, $11.4 \mathrm{~Hz}, 1 \mathrm{H}), 4.75(\mathrm{dd}, J=13.3,4.1 \mathrm{~Hz}, 1 \mathrm{H}), 3.83(\mathrm{dd}, J=11.4,4.1 \mathrm{~Hz}, 1 \mathrm{H}), 1.15(\mathrm{~s}, 3 \mathrm{H}), 1.04(\mathrm{~s}, 3 \mathrm{H})$ ppm; ${ }^{13} \mathrm{C}-\mathrm{NMR}\left(\mathrm{CDCl}_{3}\right): \delta_{C}=203.3,150.4,149.4,136.2,131.5,123.5,75.7,48.2,46.0,21.8,18.8$ ppm; HPLC: Chiralpak AD-H, $\lambda=210 \mathrm{~nm}, n$-hexane/2-propanol, 80:20, $1.0 \mathrm{~mL} / \mathrm{min}, \mathrm{t}_{\mathrm{r}}(S)=12.6 \mathrm{~min}$, $\mathrm{t}_{\mathrm{r}}(R)=14.6 \mathrm{~min}$.

3-(Furan-2-yl)-2,2-dimethyl-4-nitrobutanal (14am) [39]. Colorless oil; ${ }^{1} \mathrm{H}-\mathrm{NMR}\left(\mathrm{CDCl}_{3}\right): \delta_{H}=9.52(\mathrm{~s}, 1 \mathrm{H})$, $7.37(\mathrm{dd}, J=1.8,0.6 \mathrm{~Hz}, 1 \mathrm{H}), 6.32(\mathrm{dd}, J=3.3,1.8 \mathrm{~Hz}, 1 \mathrm{H}), 6.22(\mathrm{dd}, J=3.3,0.6 \mathrm{~Hz}, 1 \mathrm{H}), 4.76(\mathrm{dd}, J=12.9$, $11.1 \mathrm{~Hz}, 1 \mathrm{H}), 4.59$ (dd, $J=12.9,3.9 \mathrm{~Hz}, 1 \mathrm{H}), 3.93$ (dd, $J=11.1,3.9 \mathrm{~Hz}, 1 \mathrm{H}), 1.18(\mathrm{~s}, 3 \mathrm{H}), 1.05$ (s, 3H) ppm; ${ }^{13} \mathrm{C}-\mathrm{NMR}\left(\mathrm{CDCl}_{3}\right): \delta_{C}=203.4,149.7,142.7,110.4,109.6,74.8,48.1,42.2,21.1,19.0$ ppm; HPLC: Chiralpak $\mathrm{OD}-\mathrm{H}, \lambda=210 \mathrm{~nm}, n$-hexane/2-propanol, 80:20, $1.0 \mathrm{~mL} / \mathrm{min}, \mathrm{t}_{\mathrm{r}}(R)=9.0 \mathrm{~min}, \mathrm{t}_{\mathrm{r}}(S)=13.2 \mathrm{~min}$.

1-(2-Nitro-1-phenylethyl)cyclopentanecarbaldehyde (14ba) [40]. Colorless oil; ${ }^{1} \mathrm{H}-\mathrm{NMR}\left(\mathrm{CDCl}_{3}\right): \delta_{H}=9.49$ (s, 1H), 7.34-7.19 (m, 5H), $4.96(\mathrm{dd}, J=13.1,11.4 \mathrm{~Hz}, 1 \mathrm{H}), 4.68(\mathrm{dd}, J=13.1,3.8 \mathrm{~Hz}, 1 \mathrm{H}), 3.70(\mathrm{dd}, J=11.4$, $3.8 \mathrm{~Hz}, 1 \mathrm{H}), 2.07-2.03(\mathrm{~m}, 1 \mathrm{H}), 1.90-1.86(\mathrm{~m}, 1 \mathrm{H}), 1.68-1.50(\mathrm{~m}, 6 \mathrm{H}) \mathrm{ppm} ;{ }^{13} \mathrm{C}-\mathrm{NMR}\left(\mathrm{CDCl}_{3}\right): \delta_{\mathrm{C}}=204.4$, 136.4, 128.80, 128.78, 128.07, 77.3, 60.2, 49.3, 32.6, 31.5, 24.8, 24.6 ppm; HPLC: Chiralpak OD-H, $\lambda=210 \mathrm{~nm}, n$-hexane/2-propanol, 80:20, $1.0 \mathrm{~mL} / \mathrm{min}, \mathrm{t}_{\mathrm{r}}(S): 11.0 \mathrm{~min}, \mathrm{t}_{\mathrm{r}}(R): 14.4 \mathrm{~min}$.

\subsection{Computational Methods}

All reported structures were optimized at Density Functional Theory level by using the B3LYP [41-43] functional as implemented in Gaussian 09 [44]. Optimizations were carried out with the 6-31G $(\mathrm{d}, \mathrm{p})$ basis set. The stationary points were characterized by frequency calculations in order to verify that they have the right number of imaginary frequencies. The reported energy values correspond to Gibbs Free energies, including single point refinements at M06-2X/6-311 + G (d,p) [45] level of theory in a solvent model (IEFPCM, dichloromethane) [46-48] on the previously optimized structures (Supplementary Materials computed structures).

\section{Conclusions}

We conclude that readily available primary amine-salicylamides, prepared by a simple monoamidation of enantiomerically pure trans-cyclohexane-1,2-diamines, act as efficient organocatalysts in the enantioselective conjugate addition of aldehydes to nitroalkenes, leading to enantiomerically enriched $\gamma$-nitroaldehydes. Good yields and high enantioselectivities can be achieved working in the presence of DMAP as a rate-accelerating additive. Theoretical calculations suggest that the stereoselectivity is defined during the $\mathrm{C}-\mathrm{C}$ bond forming event, through a $\mathrm{H}$-bond activation of the nitroalkene with the $\mathrm{NH}$ of the amide. The approach of the alkene happens preferentially through the lower face of the enamine, where the amide group is located. Meanwhile, the rate-determining step occurs at a later stage, corresponding to the protonation of downstream stable cyclic intermediates. The ortho phenolic moiety of the catalyst is able to act as an internal proton source, and its presence increases the protonation rate, accelerating the reaction.

Supplementary Materials: The following are available online, NMR spectra, HPLC chromatograms and cartesian coordinates of the computed structures.

Acknowledgments: We thank the financial support from the Spanish Ministerio de Economía, Industria y Competitividad (CTQ2015-66624-P) and the University of Alicante (VIGROB-173, UAUSTI17-06). J.F.-F. thanks the Vicerrectorado de Investigación y Transferencia del Conocimiento de la Universidad de Alicante for a fellowship. We also thank the Basque Government (GIC15/03, IT1033-16) for financial support, and the General Research Services (IZO/SGI SGIker) of the University of the Basque Country for human and technical support. 
Author Contributions: J.R.M.-G. and J.F.-F. performed the experiments; C.G. analyzed the results; R.C. conceived, designed the experiments and wrote the paper; and E.G.-B. carried out the theoretical calculations and wrote the paper.

Conflicts of Interest: The authors declare no conflict of interest.

\section{References}

1. Aboul-Enein, M.N.; El-Azzouny, A.A.; Saleh, O.A.; Maklad, Y.A. On chemical structures with potent antiepileptic/anticonvulsant profile. Mini Rev. Med. Chem. 2012, 12, 671-700. [CrossRef] [PubMed]

2. Andresen, H.; Aydin, B.E.; Mueller, A.; Iwersen-Bergmann, S. An overview of gamma-hydroxybutyric acid: Pharmacodynamics, pharmacokinetics, toxic effects, addiction, analytical methods, and interpretation of results. Drug Test. Anal. 2011, 3, 560-568. [CrossRef] [PubMed]

3. Gajcy, K.; Lochynski, S.; Librowski, T. A role of GABA analogues in the treatment of neurological diseases. Curr. Med. Chem. 2010, 17, 2338-2347. [CrossRef] [PubMed]

4. Ono, N. The Nitro Group in Organic Synthesis; John Wiley Sons, Inc.: New York, NY, USA, 2001.

5. Goksu, H.; Sert, H.; Kilbas, B.; Sen, F. Recent advances in the reduction of nitro compounds by heterogenous catalysts. Curr. Org. Chem. 2017, 21, 794-820. [CrossRef]

6. Calderari, G.; Seebach, D. Asymmetric Michael additions. Stereoselective alkylation of chiral, non-racemic enolates by nitro olefins. Preparation of enantiomerically pure $\gamma$-aminobutyric and succinic acid derivatives. Helv. Chim. Acta 1985, 68, 1592-1604. [CrossRef]

7. Berner, O.M.; Tedeschi, L.; Enders, D. Asymmetric Michael additions to nitroalkenes. Eur. J. Org. Chem. 2002, 1877-1894. [CrossRef]

8. Sulzer-Mosse, S.; Alexakis, A. Chiral amines as organocatalysts for asymmetric conjugate addition to nitroolefins and vinyl sulfones via enamine activation. Chem. Commun. 2007, 14, 3123-3135. [CrossRef] [PubMed]

9. Roca-López, D.; Sadaba, D.; Delso, I.; Herrera, R.P.; Tejero, T.; Merino, P. Asymmetric organocatalytic synthesis of $\gamma$-nitrocarbonyl compounds through Michael and Domino reactions. Tetrahedron Asymmetry 2010, 21, 2561-2601. [CrossRef]

10. Somanathan, R.; Chávez, D.; Servin, F.A.; Romero, J.A.; Navarrete, A.; Parra-Hake, M.; Aguirre, G.; Anaya, d.P.C.; González, J. Bifunctional organocatalysts in the asymmetric Michael additions of carbonylic compounds to nitroalkenes. Curr. Org. Chem. 2012, 16, 2440-2461. [CrossRef]

11. Aitken, L.S.; Arezki, N.R.; Dell'Isola, A.; Cobb, A.J.A. Asymmetric organocatalysis and the nitro group functionality. Synthesis 2013, 45, 2627-2648.

12. Alonso, D.A.; Baeza, A.; Chinchilla, R.; Gómez, C.; Guillena, G.; Pastor, I.M.; Ramón, D.J. Recent advances in asymmetric organocatalyzed conjugate additions to nitroalkenes. Molecules 2017, 22, 895. [CrossRef] [PubMed]

13. Bennani, Y.L.; Hanessian, S. trans-1,2-Diaminocyclohexane derivatives as chiral reagents, scaffolds, and ligands for catalysis: Applications in asymmetric synthesis and molecular recognition. Chem. Rev. 1997, 97, 3161-3195. [CrossRef] [PubMed]

14. Kouklovsky, C.; Langlois, Y.; Aguilar, E.; Fernández-García, J.M.; Sikervar, V. (1S,2S)-1,2-Diaminocyclohexane. In Encyclopedia of Reagents for Organic Synthesis; John Wiley Sons, Ltd.: New York, NY, USA, 2014.

15. Zhang, X.-J.; Liu, S.-P.; Lao, J.-H.; Du, G.-J.; Yan, M.; Chan, A.S.C. Asymmetric conjugate addition of carbonyl compounds to nitroalkenes catalyzed by chiral bifunctional thioureas. Tetrahedron Asymmetry 2009, 20, 1451-1458. [CrossRef]

16. Uehara, H.; Barbas, C.F., III. anti-Selective asymmetric Michael reactions of aldehydes and nitroolefins catalyzed by a primary amine/thiourea. Angew. Chem. Int. Ed. 2009, 48, 9848-9852. [CrossRef] [PubMed]

17. Lalonde, M.P.; Chen, Y.; Jacobsen, E.N. A chiral primary amine thiourea catalyst for the highly enantioselective direct conjugate addition of $\alpha, \alpha$-disubstituted aldehydes to nitroalkenes. Angew. Chem. Int. Ed. 2006, 45, 6366-6370. [CrossRef] [PubMed]

18. Chen, J.-R.; Zou, Y.-Q.; Fu, L.; Ren, F.; Tan, F.; Xiao, W.-J. Highly enantioselective Michael addition of aldehydes to nitroolefins catalyzed by primary amine thiourea catalysts. Tetrahedron 2010, 66, 5367-5372. [CrossRef] 
19. Ma, Z.-W.; Liu, Y.-X.; Zhang, W.-J.; Tao, Y.; Zhu, Y.; Tao, J.-C.; Tang, M.-S. Highly enantioselective Michael additions of isobutyraldehyde to nitroalkenes promoted by amphiphilic bifunctional primary amine-thioureas in organic or aqueous medium. Eur. J. Org. Chem. 2011, 2011, 6747-6754. [CrossRef]

20. Guo, X.-T.; Sha, F.; Wu, X.-Y. Highly enantioselective Michael addition of $\alpha, \alpha$-disubstituted aldehydes to nitroolefins. Res. Chem. Intermed. 2016, 42, 6373-6380. [CrossRef]

21. Durmaz, M.; Sirit, A. Calixarene-based highly efficient primary amine-thiourea organocatalysts for asymmetric Michael addition of aldehydes to nitrostyrenes. Supramol. Chem. 2013, 25, 292-301. [CrossRef]

22. Ma, Z.-W.; Liu, X.-F.; Sun, B.; Huang, X.-H.; Tao, J.-C. Chiral primary amine-squaramide catalyzed highly enantioselective Michael addition of isobutyraldehyde to nitroolefins. Synthesis 2017, 49, 1307-1314. [CrossRef]

23. Fernandes, T.d.A.; Vizcaíno-Milla, P.; Ravasco, J.M.J.M.; Ortega-Martinez, A.; Sansano, J.M.; Nájera, C.; Costa, P.R.R.; Fiser, B.; Gómez-Bengoa, E. Bifunctional primary amine 2-aminobenzimidazole organocatalyst anchored to trans-cyclohexane-1,2-diamine in enantioselective conjugate additions of aldehydes. Tetrahedron Asymmetry 2016, 27, 118-122. [CrossRef]

24. Avila, A.; Chinchilla, R.; Fiser, B.; Gómez-Bengoa, E.; Nájera, C. Enantioselective Michael addition of isobutyraldehyde to nitroalkenes organocatalyzed by chiral primary amine-guanidines. Tetrahedron Asymmetry 2014, 25, 462-467. [CrossRef]

25. Flores-Ferrándiz, J.; Chinchilla, R. Solvent-dependent enantioswitching in the Michael addition of $\alpha, \alpha$-disubstituted aldehydes to maleimides organocatalyzed by mono- $N$-Boc-protected cyclohexa-1,2diamines. Tetrahedron Asymmetry 2014, 25, 1091-1094. [CrossRef]

26. Flores-Ferrándiz, J.; Fiser, B.; Gómez-Bengoa, E.; Chinchilla, R. Solvent-induced reversal of enantioselectivity in the synthesis of succinimides by the addition of aldehydes to maleimides catalysed by carbamatemonoprotected 1,2-diamines. Eur. J. Org. Chem. 2015, 1218-1225. [CrossRef]

27. Flores-Ferrandiz, J.; Stiven, A.; Sotorrios, L.; Gómez-Bengoa, E.; Chinchilla, R. Enantioselective addition of aryl ketones and acetone to nitroalkenes organocatalyzed by carbamate-monoprotected cyclohexa-1,2-diamines. Tetrahedron Asymmetry 2015, 26, 970-979. [CrossRef]

28. Flores-Ferrándiz, J.; Chinchilla, R. Organocatalytic enantioselective conjugate addition of aldehydes to maleimides in deep eutectic solvents. Tetrahedron Asymmetry 2017, 28, 302-306. [CrossRef]

29. Costes, J.-P.; Duhayon, C.; Mallet-Ladeira, S.; Shova, S.; Vendier, L. Does the sign of the Cu-Gd magnetic interaction depend on the number of atoms in the bridge? Chem. Eur. J. 2016, 22, 2171-2180. [CrossRef] [PubMed]

30. Seebach, D.; Golinski, J. Synthesis of open chain 2,3-disubstituted 4-nitroketone by diastereoselective Michael addition of $(E)$-enamines to $(E)$-nitroolefins. A topological rule for $C, C$-bond forming processes between prochiral centers. Helv. Chim. Acta 1981, 64, 1413-1423. [CrossRef]

31. Seebach, D.; Beck, A.K.; Golinski, J.; Hay, J.N.; Laube, T. Über den sterischen Verlauf von Enaminen aus offenkettigen Aldehyden und Ketonen mit Nitroolefinen zu 2,3-disubstituierten 4-Nitroketonen. Helv. Chim. Acta 1985, 68, 162-172. [CrossRef]

32. Földes, T.; Madarász, A.; Révész, Á.; Dobi, Z.; Varga, S.; Hamza, A.; Nagy, P.R.; Pihko, P.M.; Pápai, I. Stereocontrol in diphenylprolinol silyl ether catalyzed Michael additions: Steric shielding or Curtin-Hammett scenario? J. Am. Chem. Soc. 2017, 139, 17052-17063. [CrossRef] [PubMed]

33. Burés, J.; Armstrong, A.; Blackmond, D. Explaining anomalies in enamine catalysis: "Downstream species" as a new paradigm for stereocontrol. Acc. Chem. Res. 2016, 49, 214-222. [CrossRef] [PubMed]

34. Sahoo, G.; Rahaman, H.; Madarász, A.; Pápai, I.; Melarto, M.; Valkonen, A.; Pihko, P.M. Dihydrooxazine oxides as key Intermediates in organocatalytic Michael additions of aldehydes to nitroalkenes. Angew. Chem. Int. Ed. 2012, 51, 13144-13148. [CrossRef] [PubMed]

35. Rodríguez, J.M.; Pujol, M.D. Straightforward synthesis of nitroolefins by microwave- or ultrasound-assisted Henry reaction. Tetrahedron Lett. 2011, 52, 2629-2632. [CrossRef]

36. Kuster, G.J.T.; Steeghs, R.H.J.; Scheeren, H.W. Novel five/five- and six/five-membered bicyclic nitroso acetals from high-pressure-promoted cyclization reactions of $p$-methoxybenzyl vinyl ether, 1-nitro-2-heteroaryl ethenes, and mono- and di-substituted olefins. Eur. J. Org. Chem. 2001, 553-560. [CrossRef]

37. Bai, J.-F.; Xu, X.-Y.; Huang, Q.-C.; Peng, L.; Wang, L.-X. Highly asymmetric Michael additions of $\alpha, \alpha$-disubstituted aldehydes to $\beta$-nitroalkenes promoted by chiral pyrrolidine-thiourea bifunctional catalysts. Tetrahedron Lett. 2010, 51, 2803-2805. [CrossRef] 
38. Porta, R.; Coccia, F.; Annunziata, R.; Puglisi, A. Comparison of different polymer- and silica-supported 9-amino-9-deoxy-epi-quinines as recyclable organocatalysts. ChemCatChem 2015, 7, 1490-1499. [CrossRef]

39. Rasappan, R.; Reiser, O. Cyclohexane-1,2-diamines: Efficient catalysts for the enantioselective conjugate addition of ketones to nitro olefins. Eur. J. Org. Chem. 2009, 1305-1308. [CrossRef]

40. Ting, Y.-F.; Chang, C.; Reddy, R.J.; Magar, D.R.; Chen, K. Pyrrolidinyl-camphor derivatives as a new class of organocatalyst for direct asymmetric Michael addition of aldehydes and ketones to $\beta$-nitroalkenes. Chem. Eur. J. 2010, 16, 7030-7038. [CrossRef] [PubMed]

41. Lee, C.; Yang, W.; Parr, R.G. Development of the Colle-Salvetti correlation-energy formula into a functional of the electron density. Phys. Rev. B 1988, 37, 785-789. [CrossRef]

42. Becke, A.D. Density functional thermochemistry. III. The role of exact exchange. J. Chem. Phys. 1993, 98, 5648. [CrossRef]

43. Kohn, W.; Becke, A.D.; Parr, R.G. Density functional theory of electronic structure. J. Phys. Chem. 1996, 100, 12974-12980. [CrossRef]

44. Frisch, M.J.; Trucks, G.W.; Schlegel, H.B.; Scuseria, G.E.; Robb, M.A.; Cheeseman, J.R.; Scalmani, G.; Barone, V. Gaussian 09, Revision D.01; Gaussian, Inc.: Wallingford, CT, USA, 2013.

45. Zhao, Y.; Truhlar, D.G. The M06 suite of density functionals for main group thermochemistry, thermochemical kinetics, noncovalent interactions, excited states, and transition elements: Two new functional and systematic testing of four M06-class functional and 12 other functional. Theor. Chem. Acc. 2008, 120, 215-241. [CrossRef]

46. Cancès, E.; Mennucci, B.; Tomasi, J. A new integral equation formalism for the polarizable continuum model: Theoretical background and applications to isotropic and anisotropic dielectrics. J. Chem. Phys. 1997, 107, 3032-3047. [CrossRef]

47. Cossi, M.; Barone, V.; Mennuci, B.; Tomasi, J. Ab initio study of ionic solutions by a polarizable continuum model. Chem. Phys. Lett. 1998, 286, 253-260. [CrossRef]

48. Tomasi, J.; Mennucci, B.; Cancès, E. The IEF versión of the PCM solvation method: An overview of a new method addressed to study molecular solutes at the QM ab initio level. J. Mol. Struct. (Theochem) 1999, 464, 211-226. [CrossRef]

Sample Availability: Samples of the compounds $\mathbf{1 1}$ and ent-11 are available from the authors.

(c) 2018 by the authors. Licensee MDPI, Basel, Switzerland. This article is an open access article distributed under the terms and conditions of the Creative Commons Attribution (CC BY) license (http:/ / creativecommons.org/licenses/by/4.0/). 